OPINION

ZOOS' PRINT JOURNAL 20(8): 1966

\section{WILL SALE OF SPECIES NAMES HELP GROWTH OF SCIENCE?}

\author{
K.K. Verma \\ Retd. Professor of Zoology, HIG1/327, Housing Board Colony, \\ Borsi, Durg, Chhattisgarh 491001, India \\ Email:kkvermain@sancharnet.in
}

In a recent paper, Trivedi (2005), a free lance writer stationed at Washington, D.C., has brought to the attention of the scientific world a new move in taxonomy. BIOPAT (= Patrons for Biodiversity), a German non-profit organization, is offering names of newly discovered species for purchase. They keep in touch with museums and universities, which are members of BIOPAT, and which often have newly discovered animals and plants to be named and described. BIOPAT puts a price tag for naming each such new and undescribed species to be named after persons who can pay for it. The price ranges from USD3,500 to USD13,000. "... the more attractive or rare the species, the higher the price". So far more than 100 species have been sold by the organization this way, and USD450,000 have been collected. Trivedi says "The proceeds are split between the institution of the species' discovery and field research projects in the country of species origin". Thus field studies and bioconservation projects are being funded.

Trivedi has cited the example of the Vlasimisky family. Stan Vlasimisky, the head of the family and an affluent businessman, has purchased from BIOPAT coining of names of newly discovered species of an orchid, two frogs, a lizard, a butterfly and a beetle after his own name, his wife's, and of his four children. For example, a beetle has been named after Mr. Vlasimisky as Eupholus vlasimiskyi.

The Wildlife Conservation Society (WCS) has followed the footsteps of BIOPAT, but has taken to an on-line auction of naming new species. The Australian Museum in Sydney too has such a name selling project, but has been less successful than BIOPAT.

In the year 2000 ICZN (= International Commission on Zoological Nomenclature) pointed out the possibility of "fraudulent species description" on attaching financial gain to naming of species. But the present President of ICZN, while not denying the demerits of this practice as pointed out earlier by the Commission, expresses at the same time a plus point in it. He says that governmental funding of field research and bioconservation projects is very inadequate, and selling and auctioning of new species for naming has succeeded in providing finances. There are some others also, who believe that this new taxonomic practice is useful.

When discussing merits and demerits of sale of new species for naming, let us recall how a new species is made out. Current notion of a species is that of a biological species, which was defined by Mayr (1940) as "Species are groups of actually or potentially interbreeding natural populations, which are reproductively separated from similar other populations". Definitions, conveying the same meaning, were given by Mayr in several of his subsequent publications. When a field worker or a collector collects a strange animal or plant, in order to ascertain that it is a new species it should be found out whether it is reproductively isolated from other similar organisms, the species identity of which is on record. But determination of this reproductive isolation is very difficult, as it requires either extensive field observations or arranging breeding experiments. These steps are often not feasible. In most cases the isolation is inferred from distinctness of phenotypic features, and generally thus identified and named species are stable, though in some cases synonymisation and thus merger of some species has to be done (some recent examples of this: Kalaichelvan et al., 2003; Verma \& Kalaichelvan, 2004). But, if financial aid factor is appended to field study and taxonomy projects through sale or auction of naming of new species, some premature decisions as to novelty of species are likely to be encouraged, as such projects generally suffer from lack or inadequacy of supporting funds. Compromising ethics will definitely lead to the creation of 'artificial biodiversity', which will further require massive work by taxonomists to standardize and sort synonymies. Will, then, this sale of species names not hamper growth of biological sciences?

The other new trend of naming species after prominent politicians is deplorable. Recently three slime-mold beetles have been named by Miller and Wheeler (2005) after three eminent leaders of USA, Agathidium bushi (after President Bush), Agathidium cheneyi (after Vice-President Cheney) and Agathidium rumsfeldi (after Secretary of Defence Donald Rumsfeld). It is not reasonable to club together this trend with the sale of species names, but I would like to emphasize here that politicians, as it is gain enough popularity, and go down in history. It is scientists, who remain in relative oblivion, and need recognition. Will it not be better to adhere to the old practice, namely that, if a person's name or "proper noun" is to be used in naming a species, a scientist's name is chosen?

\section{REFERENCES}

Kalaichelvan, T., K.K. Verma and B.N. Sharma (2003). Experimental, morphological and ecological approach to taxonomy of Oriental species of Lema (Insecta, Coleoptera, Chrysomelidae). Bonner Zoologische Beitrage 51(4): 255-260.

Mayr, E. (1940). Speciation phenomenon in birds. American Naturalist 74: 249-278.

Miller, K.B. and Q.D. Wheeler (2005). Slime-mold beetles of the genus Agathidium Panzer in North and Central America, Part II Coleoptera: Leiodidae. Bulletin of the American Museum of Natural History, 291: 1- 167. (Cited on the strength of an item appearing in the Los Angeles Times of April 13, 2005, entitled "Beetles Get Politically Prominent Names").

Trivedi, B.P. (2005). What's in a species name? More than 450000 dollars. Science 307: 1399. 4 March 2005.

Verma, K.K. and T. Kalaichelvan (2004). Polymorphism and microtaxonomy in Chrysomelidae. In: New Developments in the Biology of Chrysomelidae (Editors: P. Jolivet, J.A. Santiago-Blay and M. Schmitt). S.P.B. Academic Publishing b.v., The Hague, The Netherlands. pp. 213278.

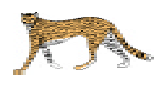

